TAPROBANICA, ISSN 1800-427X. April, 2013. Vol. 05, No. 01: pp. 89-93.

(C) Taprobanica Private Limited, 146, Kendalanda, Homagama, Sri Lanka.

www.taprobanica.org

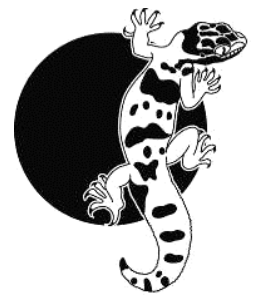

\section{Himalayan Yellow-throated Marten (Martes flavigula) in West Bengal, India}

The nominate race of Martes flavigula Boddaert, 1785 (Mammalia: Carnivora: Mustelidae), popularly known as Himalayan Yellow-throated Marten (Fig. 1), is the largest among the old world martens and has unique colour blends of black, white, golden-yellow and brown, relatively short fur and a long tail. It is distinguished from eight other recognized races of the species by the absence of a naked area of skin above the planter pad of the hind foot, a large mat of hair between the planter and carpal pads of the forefoot, and by its longer, more luxuriant winter coat (Pocock, 1941). This study was initiated to (1) collect the past and contemporary locality records, (2) describe the natural history and ecology of the species, and (3) assess its conservation status in the hill forests of northern West Bengal, India.

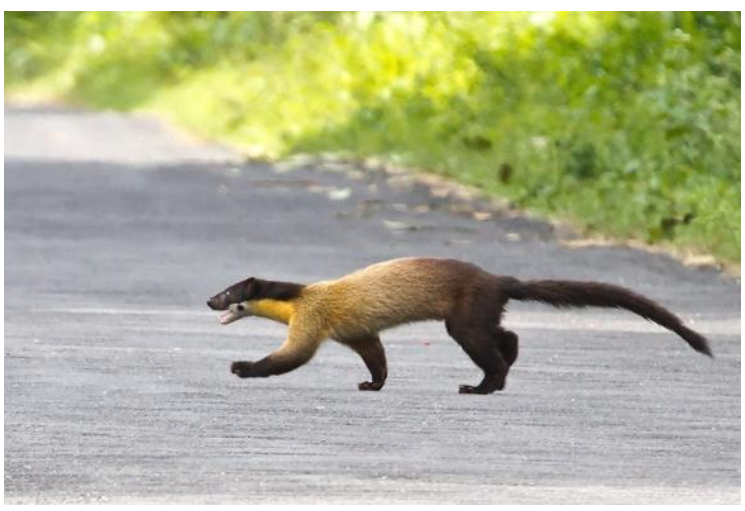

Figure 1: A Yellow-throated Marten is crossing a road in Buxa Tiger Reserve

The study was conducted from $1^{\text {st }}$ January 2011 to $31^{\text {st }}$ December 2011 . The study area covers $1,254 \mathrm{~km}^{2}$ hill forests within the altitudinal range of 300-3,650 $\mathrm{m}$ a.s.l. in the hilly terrain of Darjeeling and Jalpaiguri districts, particularly the Protected Areas (PAs) and contiguous Reserve Forests (RFs) in the mountain ranges of Singalila-DarjeelingKurseong (west of the River Teesta) and Chola (Kalimpong)-Sinchula (Buxa-Jainti) (east of the River Teesta). Information was obtained about probable habitats through discussions and questionnaire-based interviews with 106 persons (30 forest department field staff and 76 others including villagers, members of the local forest protection / eco-development committees, and wildlife watchers / photographers). To ensure accuracy, I showed photographs and drawings of $M$. flavigula to these individuals. In addition, the relevant camera trap data previously obtained from Senchal during September-November 2010 were used. Presence of the species in an area was recorded through approximately $400 \mathrm{hr}$ of daytime survey that used the existing trails (264 $\mathrm{km})$ and open sandbanks $(157 \mathrm{~km})$.

Yellow-throated Marten was recorded from thirty-five locations in six disjointed PAs and surrounding RFs. Out of 41 encounters recorded, 34 were solitary, 3 pairs, 2 trios, 1 small pack (4) and 1 large pack consisting of 7 adults and 3 young animals that was observed on the undisturbed Katlung riverbank $\left(26^{\circ} 45^{\prime}\right.$ $\mathrm{N}$ and 89 $36^{\circ}$ E) in Buxa Tiger Reserve. Museum specimens were collected from Darjeeling (4), Kurseong (1), Kalimpong (1) and Jalpaiguri (1) during $20^{\text {th }}$ century. These specimens include one female from the dense forest on the east bank of River Torsa in Jalpaiguri $\quad\left(26^{\circ} 50^{\prime} \mathrm{N}, \quad 89^{\circ} 20^{\prime} \mathrm{E} ; \quad 246 \mathrm{~m}\right.$ (Wroughton, 1917a), another female from Pedong $\left(27.15^{\circ} \mathrm{N}, 88.62^{\circ} \mathrm{E} ; 1,240 \mathrm{~m}\right)$ in Kalimpong (Wroughton, 1917b), a male from Darjeeling (the exact locality, year of collection, name of the collector and other particulars not given), Bengal Natural History Museum [Reg. No. BNHM/M 15] (Saha \& Singhal, 1996) and an unsexed specimen (NRM Mammals 605063) from Siliguri $(150 \mathrm{~m})$, Darjeeling (http://www.ebiodiversity.net/ mammals/mammalia/carnivora/mustelidae/mart es-flavigula).

Yellow-throated Martens mark their range with faeces and urine and animals often defecates in 
the open areas and prominent places like stone walls and sandbanks. Several fresh scats, putatively of $M . f$. flavigula (black, elongated spiral strip tapering at one end, $8-9.2 \mathrm{~cm}$ in length, $1-1.5 \mathrm{~cm}$ in width, weight $2-8.3 \mathrm{~g}$ ), were collected from Singalila and Neora Valley National Parks and plant parts and intact seeds or fragments were identified in the scats (see also Chakraborty et al., 2008).

Sub-populations are restricted to only $33.2 \%$ $\left(855 \mathrm{~km}^{2}\right)$ of the $19^{\text {th }}$ century range in north Bengal $(2,572 \mathrm{~km})$. During the early twentieth century, it was widely distributed in the forests of Bengal terai including Darjeeling (Wroughton, 1916), Bhutan duars, i.e. present Hasimara-Buxa subregion (Wroughton, 1917a), Kalimpong (Wroughton, 1917b) and Jalpaiguri (Inglis et al., 1919). During early $20^{\text {th }}$ century several individuals were shot in the forests of Darjeeling at moderate elevations and many were sighted in the tea gardens (Dalgliesh, 1917). The only occurrence at lower elevation $(246 \mathrm{~m})$ was recorded from Hasimara $\left(26^{\circ} 45^{\prime}-26.75^{\circ} \mathrm{N} ; \quad 89^{\circ} 21^{\prime}-89.35^{\circ} \mathrm{E}\right) \quad$ of Jalpaiguri (Wroughton, 1917a). Choudhury (1999) has observed that it is very rare in southern Jalpaiguri and its presence in Cooch (= Koch) Behar (= Bihar) district is doubtful and, in all probability, it is locally extinct there.

The study area covers the Lower Hill (3001,000 m), Middle Hill (1,001-1,950 m), Upper Hill (1,951-3,500 m) and Subalpine Forests (above 3,500 m). Whereas Sanyal (1999) recorded that this species occurs in the higher elevations, it was found in both middle and higher hills $(1,219-2,743 \mathrm{~m})$ in Neora Valley National Park (Mallick, 2012). The present study recorded the species from the lower, middle, and higher ranges with variation in sighting frequency. It was sighted mostly in the East Himalayan Moist Temperate Forests and Northern Montane Wet Temperate Forests, especially where Rhododendron and Querques spp grow profusely in contrast to lowest frequency in the Sub-Alpine Forests $\left(14 C_{2}\right)$ and East Himalayan Subtropical Wet Hill Forests. The altitudinal range of the species was between $560 \mathrm{~m}$ in Tobgaon Forest Block of Buxa to 3,323 m in Sandakphu of Singalila. An individual was camera-trapped on the forest floor covered with ferns within a Quercus forest in Senchal. It was sighted in the undisturbed hilly terrain, undulating ground, slopes, narrow river valleys and along the basins that lay downstream and also on the upper reaches of streams.

This species uses a variety of den sites; rock crevices, tree cavities, under root wads, subterranean burrows, old bird nests, squirrel dreys and in or under logs (hollow or solid). It also uses the tree branches, which are normally located several metres off the ground in forest canopy or upturned/blown over trees, as refuge sites.

Yellow-throated Marten is mostly diurnal in the undisturbed forests, but becomes nocturnal near the human habitations. A large group was observed during mid-day in Buxa. The camera-trap study in Senchal reported its Daily Activity Index (DAI) [No. of photos in a duration/Total no. of photos captured of a species $\times 100$ ] between $06.00 \mathrm{~h}-18.00 \mathrm{~h}$ (Sunar et al., 2012). The enclave and fringe villagers confirmed its nocturnal raids in the fowl houses.

It is predominantly a carnivore preying on the smaller ungulates, primates, rodents, reptiles, and birds. A pair was reported to run down a Barking Deer (Muntiacus vaginalis) fawn (Wroughton, 1916). In the study area, it also preyed on Himalayan Tahr Hemitragus jemlahicus, Indian Goral Naemorhedus goral, and flying squirrels (Petaurista spp). A marten chased a monkey on the tree top, but could not capture it. Then it hunted a rat on the same spot. One was seen pursuing an Irrawaddy squirrel (Callosciurus pygerythrus lokroids) in Neora Valley. It was also reported to prey on the red panda (Ailurus fulgens) cubs in both Singalila and Neora Valley National Parks.

It was seen to climb a vertical tree and hunt a pheasant by chasing it on the ground and then following it up the tree. It was reported to kill chicks from the bird nests and to cause predation on the captive stock of pheasants (Blood pheasant Ithaginis cruentus, Satyr tragopan Tragopan satyra, Himalayan monal Lophophorus impejanus, Kalij pheasant Lophura leucomelanos) in Padmaja Naidu

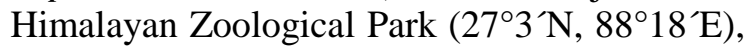
Darjeeling (Bahuguna \& Mallick, 2010).

It forages for fruits in trees in both the lower and upper reaches of the canopy and on the 
ground. During dry season, it was seen to consume ripe fruits of Rhododendron spp, lick sap from the bark and nectar from the flowers bloomed in April-June and Simul (Bombax ceiba) flowers in March-April by thrusting its nose into the flower cup. It was seen eating bees at the entrance to the hive. It often uproots the hives from the large branches of trees and, being a wasteful feeder, known to cause excessive damage. H. V. O'Donel found this animal tearing up the partly deserted hive of the jungle bee (Inglis et al., 1919). After eating all the combs and brood, it urinates on the hive probably to mark their territory.

Hairs and skeletons of the mammalian species (Soricomorpha, Sciurinae, Pteromyinae, Artiodactyla, Chiroptera and unknown species), bird feathers, egg shells, reptile scales, insect (arthropods) exoskeletons, fruits, plant debris including fungi, mud and unknown residuals were found in the faecal samples collected in Neora Valley and Singalila National Parks.

This marten is known to breed between either February and March or June and August and gestation lasts for 220-290 days. In the study area, they were reported to mate in August and give birth to their kits (up to 3 ) in the natal dens in April (Das 2010).

Human-marten conflict was reported from fringe villages of remote mountainous areas causing depredation on the domestic animals. About $50 \%$ of the wildlife depredation on the village livestock in and around Senchal was caused by the Yellow-throated Marten alone (Sunar et al., 2012). Sections of village were fenced using a combination of mailing bamboo, barbed wire and plants, which was found to be ineffective. Human-marten conflict around Singalila and Senchal was the highest in the study area.

There is little information on the population status and trends of Yellow-throated Marten. The species was more plentiful near Darjeeling (Wroughton 1916). It was evidently common in Darjeeling, but rare in the northern areas of Jalpaiguri (Agrawal et al., 1992; Choudhury, 1999). Even during the early $20^{\text {th }}$ century it was uncommon in Jalpaiguri (Inglis et al., 1919). During the late $20^{\text {th }}$ century it was very common in Victoria and Dow Hill area of Kurseong (Banerjee, 1995). It was also common in the higher elevations of Neora Valley and frequently sighted in Joributi and upper Rachila Chawk (Mallick, 2012).

The census in Darjeeling district recorded an estimated population of 811 (Singalila NP: 132, Neora Valley NP: 226, Senchal WS: 148, Darjeeling Division: 41, Kurseong Division: 108, Kalimpong Division: 63 and Darjeeling Gorkha Hill Council Forest: 93) in 2002. But no census was conducted in Jalpaiguri district. Based on the present field survey, the total population in northern Bengal is estimated to be less than 1,000. Recently, 7 martens were camera-trapped in Senchal and the photo capture rate or Relative Abundance Index (RAI) [Total no. of photos captured of the species/Total trap nights $\times 100$ ] was assessed to be less than 2 (Sunar et al., 2012).

The main threat is habitat destruction and fragmentation, conversion of forest land for the agriculture, tea, livestock grazing, collection of firewood and fodder. $20 \%$ of the forest had been converted to plantations by 1980 . Much of the natural forests in the Senchal, GhumSimana and Takdah ranges of Darjeeling have been converted. $21.8 \%$ forests of Darjeeling and $23.3 \%$ of Jalpaiguri are also degraded. There was marked decline in the forest cover in Takdah-Ghoom-Simana of Darjeeling Sadar, Sukna, Pankhabari region of Kurseong and Chel and Jaldhaka catchments of Kalimpong. Yellow-throated Marten is also threatened by poaching for its pelt, but due to the nasty aroma of its meat, it is not hunted for food. Although poaching incidents are not common in the study area, hunting outside the PAs is not currently regulated effectively, especially in the fringe areas. On 22 October 2011, carcass of a Yellow-throated Marten was detected on the bank of the River Diana near Chamurgachhi in North Diana block on the Indo-Bhutan border in Jalpaiguri, which was reportedly killed, chopped and skinned by the villagers. This is the first record of this marten in the northern part of Jalpaiguri Forest Division.

M. flavigula is classified as 'Least Concern' on the IUCN Red List due to its wide distribution, evidently relatively stable population, occurrence in a number of PAs and lack of major threats (Abramov et al., 2008). But, this species is considered threatened or endangered in India. It is listed under Schedule II (Part II: 
2-E) of the Indian Wildlife (Protection) Act 1972 [vide S.O. 859(E), dated 24 November 1986, published in the Gazette of India, Extraordinary, Pt. II, Sec. (i)], which provides absolute protection to this species, i.e. the offences are prescribed the highest penalties as per Section 51 of the said Act.

The PAs, harbouring the Yellow-throated Marten, are scattered 'conservation islands'. The species also occurs in non-PAs (RFs), where the habitat and habitants are not strictly protected. $532.2 \mathrm{~km}^{2}$ of BTR (inclusive of $459.1 \mathrm{~km}^{2}$ of the protected area the entire NP, WLS and $73.1 \mathrm{~km}^{2}$ buffer area) has been notified as inviolate 'Critical Wildlife Habitat' and the hills and foothill forests of eight blocks are being preserved as 'eco-sensitive sites'. But, major parts of the habitat in the study area are under-staffed for regular intensive patrolling and protection. Whereas natural protection and absence of commercial exploitation in the steep northern section of the study area has led to maintenance of large patches of stable forests, substantial recovery has taken place in the southern part consequent upon the Supreme Court of India's ban on exploitation and collection of forest resources since 1996. Moreover, supplementary support of the fringe communities is required for conservation of the species and its habitats. More research including radio-collaring and tracking of the aberrant martens causing livestock depredation in the villages is required in order to develop a species-specific sound management programme in the study area.

\section{Acknowledgements}

I am grateful to all the local field staff and resource persons in the forest department as well as the researchers, photographers, WWFIndia, Eastern Region and respondents to the questionnaire survey. Finally I would like to thank Colin Chapman (McGill University Canada) for editing the manuscript.

\section{Literature cited}

Abramov, A., R. J. Timmins, S. Robertson, B. Long, Than Zaw and J. W. Duckworth, 2008. Martes flavigula, In: IUCN 2011. IUCN Red list of Threatened Species. Version 2011.2. www.iucnredlist.org. Downloaded on 05 January 2012.
Agrawal, V. C., P. K. Das, S. Chakraborty, R. K. Ghose, A. K. Mandal, T. K. Chakraborty, A. K. Poddar, J. P. Lal, T. P. Bhattacharya and M. K. Ghosh, 1992. Mammalia, In: State fauna series 3: Fauna of West Bengal, part I [overview, Mammalia, Aves and Wildlife], Director, Zoological Survey of India. Zoological Survey of India, Calcutta, India: 27-155.

Bahuguna, N. C. and J. K. Mallick, 2010. Handbook of the mammals of South Asia. Natraj Publishers, Dehradun, India: 541.

Banerjee, A. 1995. Victoria in her environment. Victoria School Centenary Magazine. johnf. http://www.vsdh.org/vsdh/magazines/vs_centenar $y /(16) . h t m l$.

Chakraborty, S., P. Dey, S. Tripathi, S. Jana and A. Dey, 2008. Report on the status of Clouded leopard Neofelis nebulosa (Griffith) and Hodgson's flying squirrel Petaurista magnificus (Hodgson) in Neora Valley National Park, Darjeeling, West Bengal (Survey period 20062007). Project funded by Department of Forest, Government of West Bengal. Nature, Environment and Wildlife Society (NEWS), Kolkata, India: 52.

Choudhury, A. U., 1999. Conservation of small carnivores (mustelids, viverrids, herpestids, and one ailurid) in north Bengal, India. Small Carnivore Conservation, 20: 15-17.

Dalgliesh, G., 1917. Notes and observations on mammals collected and observed in the Darjeeling district, India. Journal of the Bombay Natural History Society, 17 (1): 122-127.

Das, T., 2010. A note book on biodiversity of Neora Valley National Park. Department of Forests, Government of West Bengal: 212.

Inglis, C. M., W. L. Travers, H. V. O'Donel and E. O. Shebbeare, 1919. A tentative list of the vertebrates of the Jalpaiguri district, Bengal. Journal of the Bombay Natural History Society, 26 (3): 819-825.

Mallick, J. K., 2012. Mammals of Kalimpong Hills, Darjeeling district, West Bengal, India. Journal of Threatened Taxa, 4 (12): 3103-3136.

Pocock, R. I., 1941. Fauna of British India: Mammals. Vol.2. Taylor and Francis, London: 463. 
Saha, S. S. and N. Singhal, 1996. Mammalian specimens of Bengal Natural History Museum, Darjeeling. Department of Forest (Wildlife Wing), Government of West Bengal, Darjeeling, India: 168.

Sanyal, P., 1999. Common Mustelids, Viverrids and Herpestids of West Bengal. Envis Bulletin: Wildlife and Protected Areas 2 (2): 59-61.

Sunar, D., R. Chakraborty, B. K. Sharma, P. S. Ghose, P. T. Bhutia and S. Pradhan, 2012. Status and distribution of Asiatic Black Bear and the status of human-bear conflict at Senchal Wildlife Sanctuary, Darjeeling, West Bengal, India: Technical Report. WWF-India, Khangchendzonga Landscape Programme, Darjeeling and Sikkim and West Bengal Forest Department, Wildlife Division 1, Government of West Bengal, India: 48.

Wroughton, R. C., 1916. Bombay Natural History Society's mammal survey of India, Burma and Ceylon, Report No. 23, Sikkim and Bengal Terai. Journal of the Bombay Natural History Society, 24 (3): 468-493.

Wroughton, R. C., 1917a. Bombay Natural History Society's mammal survey of India, Burma and Ceylon, Report No. 27, Bhutan duars. Journal of the Bombay Natural History Society, 25 (1): 63-71.

Wroughton, R. C., 1917b. Bombay Natural History Society's mammal survey of India, Burma and Ceylon, Report No. 28, Kalimpong (Darjeeling). Journal of the Bombay Natural History Society, 25 (2): 274-278.

Submitted: 25 Jan 2012, Accepted: 08 March 2013 Sectional Editor: Colin Chapman

\section{Jayanta Kumar Mallick}

Wildlife Wing (Headquarters), Forest Directorate, Government of West Bengal, Bikash Bhawan, North Block, $3^{\text {rd }}$ floor, Salt Lake City, Kolkata 700091, India

E-mail: jayantamallick2007@ rediffmail.com 